\title{
SCHOLING
}

Het Pedicure Thema
Scholing

Leren doe je op school, maar vooral ook van elkaar. Al 5 jaar hebben 13 pedicures en een podotherapeut een overleg waarin jong en oud(er) elkaar goed aanvult. Verder in het thema scholing een artikel over wat je met voetreflexologie kunt toevoegen (pag. 16). En uiteraard hebben we ook dit jaar weer het scholingsoverzicht op onze website (zie pag. 19).

\section{Kennis opdoen}

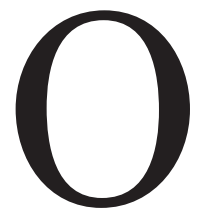

ver kennis bestaan veel uitspraken, de zogenoemde tegelwijsheden, zoals Ervaring delen, is kennis vermeniguuldigen, Kennis is macht, maar kennis delen is kracht, Als je al meent dat je het weet, zul je nooit iets te weten komen. De mooiste vind ik misschien nog wel Wie denkt dat kennis duur is, vergist zich in de kosten van onwetendheid. Zelf ben ik in januari van dit jaar naast mijn werk een 5 -daagse training begonnen. Weliswaar verspreid over 5 maanden, omdat er tussentijds het nodige huiswerk gedaan moet worden. Ik moet zeggen dat ik er enorm van geniet. Vooral door de nodige eyeopeners die de training geeft. Dat ik iets nieuws leer dat ik direct kan toepassen in de praktijk, geeft een heel energiek gevoel. Was de training duur? In euro's bijna 2000. Dus ja, dat is een hoop geld, maar wat ik er voor terugkrijg, vind ik onbetaalbaar. Daarnaast geeft het mij ook een goed gevoel om in mezelf te investeren. Vanaf september ga ik op mijn $53^{\mathrm{e}}$ een jaar lang op mijn vrije dag zelfs weer een nieuwe opleiding volgen. Uiteraard eerst geïnformeerd of de opleiding te volgen is naast een 32-urige werkweek. Maar dat kan blijkbaar.

In de pedicurebranche zie ik verschillende reacties op scholing. 'Ik moét wel scholing volgen, anders haal ik mijn accreditatiepunten niet' of 'het kost allemaal zoveel geld'. Het opdoen van kennis hoeft niet altijd geld te kosten. Je kunt ook met collega's afspreken om een dagje in elkaars praktijk mee te lopen, of intercollegiaal overleg houden, casuïstiek bespreken, noem maar op. Wat betreft de uitspraak 'Ik moet wel..., zodra je het gevoel hebt dat iets 'moet', schiet je lichaam in de stress. Je ziet er als een berg tegenop en wordt onrustig. Een andere reactie op scholing is: 'Leuk, ik mag weer.' Bij deze reactie krijg je energie in plaats van dat het je energie kost. Probeer het eens consequent uit: vervang het woord 'moeten' eens door 'kunnen', 'willen' of 'mogen'. Dat zal niet makkelijk zijn, want het woord 'moeten' zit flink ingebakken in ons taalgebruik, maar kijk eens wat het met je doet als je het een tijd lang vervangt.

In de tussentijd vind je op de website van Podopost weer een overzicht van scholingsmogelijkheden voor de komende tijd.

Maureen Limpens, hoofdredacteur m.limpens@bsl.nl

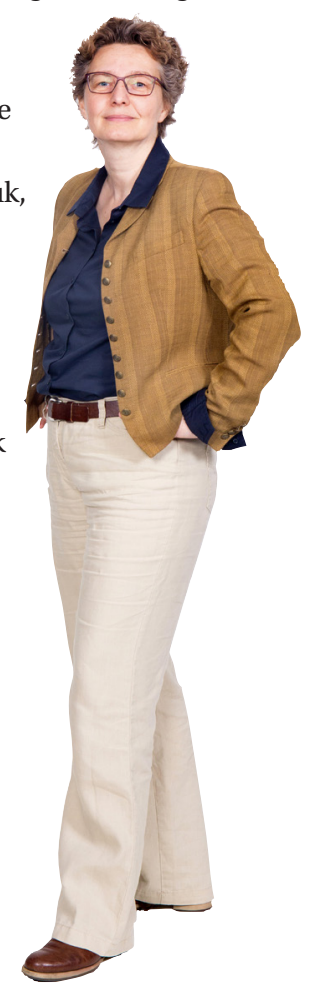

